The Common Agricultural Policy of the European Union the present and the future

Non-EU Member States point of view 



\section{INSTITUTE OF AGRICULTURAL AND FOOD ECONOMICS NATIONAL RESEARCH INSTITUTE}

\section{The Common Agricultural Policy of the European Union - the present and the future}

\section{Non-EU Member States point of view}

Editors:

dr Marek Wigier

prof. dr hab. Andrzej Kowalski

Proceedings of the International Scientific Conference

"The Common Agricultural Policy of the European Union - the present and the future" Multi-Annual Programme 2015-2019

"The Polish and the EU agricultures 2020+. Challenges, chances, threats, proposals" 5-7 December 2017 Stare Jabłonki, Poland

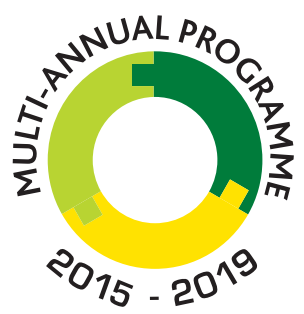

THE POLISH AND THE EU AGRICULTURES 2020+ CHALLENGES, CHANCES, THREATS, PROPOSALS

Warsaw 2018 
This monograph was prepared under the Multi-Annual Programme 2015-2019

"The Polish and the EU agricultures 2020+. Challenges, chances, threats, proposals".

The publication is a collection of selected papers delivered at the 22th edition of the International Scientific Conference organized by the Institute of Agricultural and Food Economics - National Research Institute. The theme of the conference was "The Common Agricultural Policy of the European Union the present and the future. The conference was placed on 5-7 December 2017 in Stary Jabłonki in Poland. Common Agricultural Policy was and still is one of the key pillars of European integration. Published in two volumes materials refer directly to the current and future of the CAP in EU and non EU member states, the strategic objectives and principles of agricultural policy for the agri-food sector and rural areas, address the issues of equilibrium between agriculture, forestry and land use, relate to the dilemmas for the EU budget and the CAP after 2020, CAP instruments and their adjustment, transformations of the rural economy and programming of the rural and agricultural policy, as well as productivity and production efficiency and tensions between sectoral action and between different models of territorial activities.

In the Scientific Committee of the Conference was participated: Prof. Andrzej Kowalski (IAFE-NRI, Poland), Prof. Drago Cvijanonivić (University of Kragujevac, Serbia), Prof. Thomas Doucha (IAEI, Czech Republic), Noureddin Driouech, PhD (CIHEAM, Italy), Prof. Szczepan Figiel (IAFE-NRI, Poland), Prof. Masahiko Gemma (Waseda University, Japan), Prof. Wojciech Józwiak (IAFE-NRI, Poland), Prof. Jacek Kulawik (IAFE-NRI, Poland), Prof. Yuriy Oleksiyovych Lupenko (IAE, Ukraina), Prof. Věra Majerová (CULS, Prague), Prof. Dimitre Nikolov (IAE, Bulgaria), Maire Nurmet, PhD (EMÜ, Estonia), Prof. Gabriel Popescu (ASE, Romania), Norbert Potori, PhD (AKI, Hungary), Prof. Włodzimierz Rembisz (IAFE-NRI, Poland), Piotr Szajner, PhD (IAFE-NRI, Poland), Prof. Alina Sikorska (IAFE-NRI, Poland), Prof. Jonel Subić (IAE, Serbia), Prof. Samuele Trestini (UNIPD, Italy), Prof. Olga Varchenko (Bila Tserkva National Agrarian University, Ukraine), Dipl.-Ing. Klaus Wagner (AWI, Austria), Marek Wigier, PhD (IAFE-NRI, Poland), Prof. Józef St. Zegar (IAFE-NRI, Poland)

In the Organising Committee of the Conference was participated: Małgorzata Bułkowska (IAFE-NRI, Poland), Anna Hankiewicz (IAFE-NRI, Poland), Joanna Jaroszewska (IAFE-NRI, Poland), Joanna Korczak (IAFE-NRI, Poland), Krzysztof Kossakowski (IAFE-NRI, Poland), Irena Mikiewicz (IAFE-NRI, Poland), Małgorzata Mikołajczyk (IAFE-NRI, Poland), Lech Parzuchowski (IAFE-NRI, Poland), Ewa Sierakowska (IAFE-NRI, Poland), Paulina Smakosz (IAFE-NRI, Poland), Leszek Ślipski (IAFE-NRI, Poland), Marek Wigier, PhD (IAFE-NRI, Poland).

Reviewers:

Professor Dimitre Nikolov, Institute of Agricultural Economics, Sofia, Bulgaria

Professor Gabriel Popescu, The Bucharest University of Economic Studies, Bucharest, Romania

Professor Samuele Trestini, University of Padva, Italy

Proofreader

Joanna Gozdera

Technical editors:

Joanna Jaroszewska, Barbara Pawtowska, Ewa Sierakowska, Kamila Tomaszewska,

Barbara Walkiewicz

Translated by

Summa Linguae S.A.

Cover Project

Leszek Ślipski

ISBN 978-83-7658-744-8

DOI: $10.30858 / \mathrm{pw} / 9788376587448$

Instytut Ekonomiki Rolnictwa i Gospodarki Żywnościowej

- Państwowy Instytut Badawczy

ul. Świętokrzyska 20, 00-002 Warszawa

tel.: (22) 5054444

faks: (22) 5054636

e-mail:dw@ierigz.waw.pl

http://www.ierigz.waw.pl 


\section{Contents}

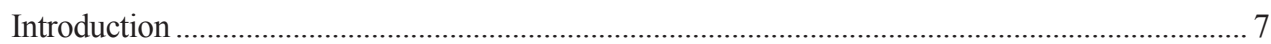

1 Urban agriculture: a framework for agricultural policy - present and future ......................... 15

Prof. Drago Cvijanović, Prof. Otilija Sedlak, Ph.D. Željko Vojinović

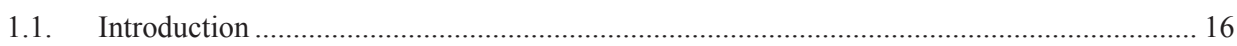

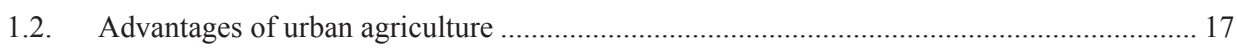

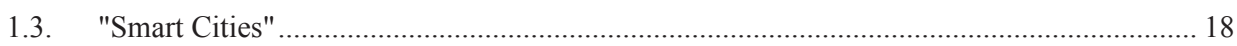

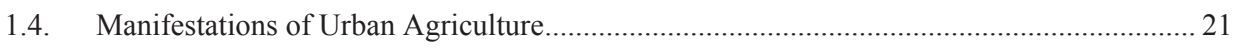

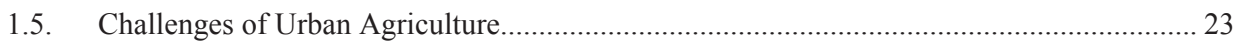

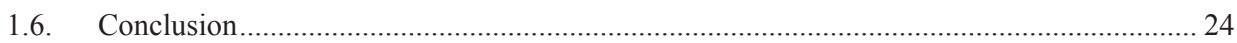

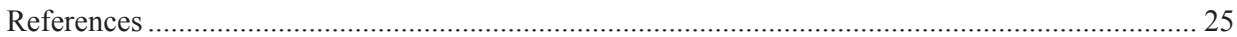

2 Land market and a village-keeping model of the agrarian system of Ukraine....................... 27

Dr Iurii Lupenko, Dr Valerii Zhuk

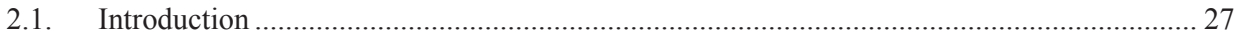

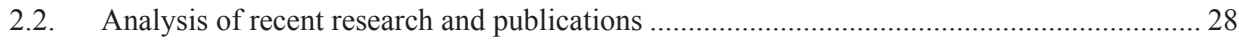

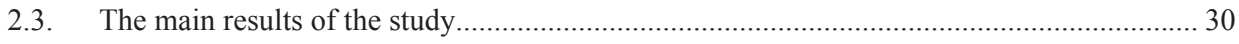

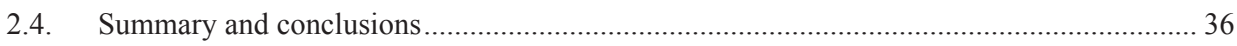

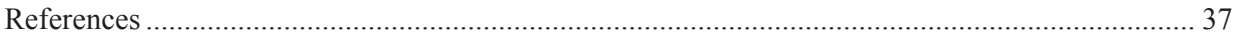

3 Agrarian policy in the European Union and financial support to Serbia................................ 38

PhD Biljana Grujić, PhD Predrag Vulović

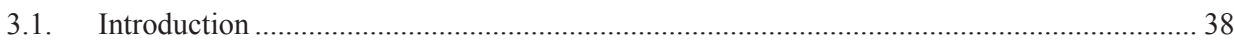

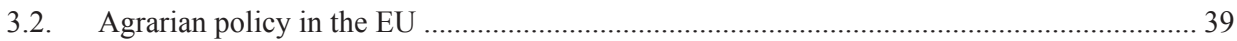

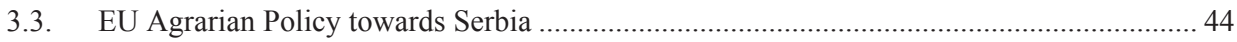

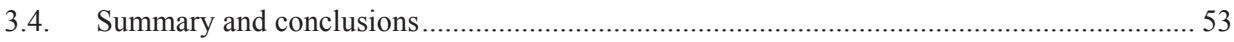

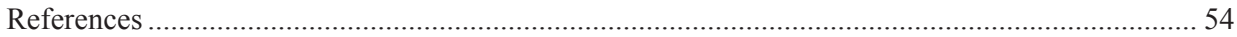

4 Ukrainian agricultural market regulation tools: their effectiveness and directions

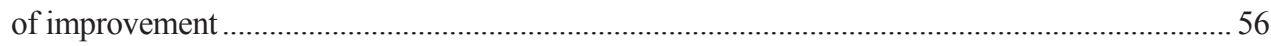

Prof. Olga Varchenko

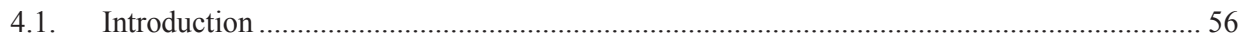

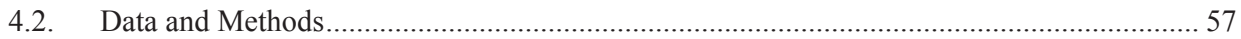

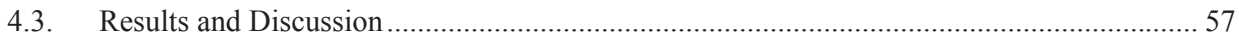

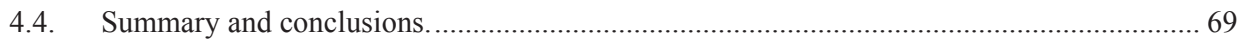

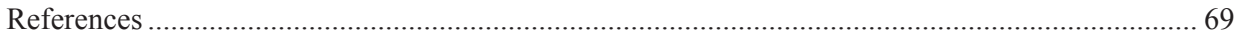


5 The Common Agricultural Policy of the European Union and the ways of its implementation in Ukraine

Dr Vasyl D. Zalizko, Prof. Nataliia M. Vdovenko, PhD Violeta L. Heraimovych, Assoc. Prof.

5.1. Introduction .71

5.2. The evolution of the EU Common agricultural policy .72

5.3. New priorities of the European Union for 2014-2020: strategic directions for Ukraine's agricultural sphere development

5.4. Organic component of the agricultural policy of Ukraine and common agricultural policy of the EU

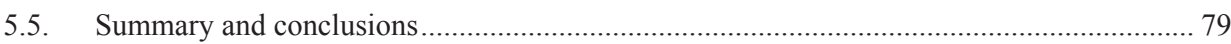

References 80

6 Farm's financing patterns and financial system development: evidence from Ukraine and Poland

Prof. Olena Oliynyk-Dunn, Prof. Viktor Adamenko

6.1. Introduction 81

6.2. Research methods 83

6.3. Results 84

6.4. Summary and conclusions 95

References .96

7 The moratorium on agricultural land sale as a limiting factor for rural development 97

Prof. Anatoliy Danylenko, PhD Tetyana Sokolska, PhD Olena Shust

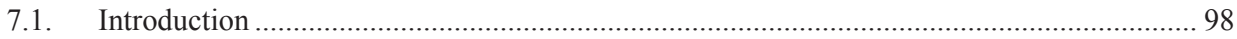

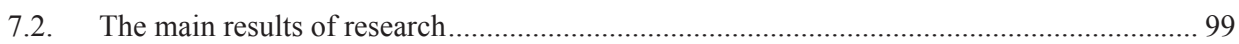

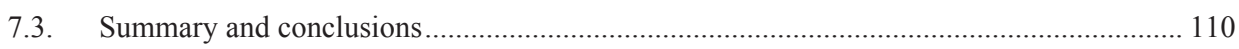

References

8 Solutions to the problems of rural territories development as a sign of their positive brand 114 Prof. Oleksandr Pavlov, Iryna Pavlova

8.1. Introduction 114

8.2. Problems of rural territories development 117

8.3. Branding as a marketing tool for solving the problems of rural territories development.... 124

8.4. Brand of rural territories development in Ukraine 127

8.5. Summary and conclusions 131

References 132

Instead of a summary 133

Annex I 


\title{
4 Ukrainian agricultural market regulation tools: their effectiveness and directions of improvement
}

\author{
Prof. Olga Varchenko, Bila Tserkva National Agrarian University \\ Department of Finance, banking and insurance \\ Bila Tserkva, Ukraine, \\ e-mail:omvarchenko@ukr.net
}

DOI: $10.30858 / \mathrm{pw} / 9788376587448.4$

\begin{abstract}
In the conditions of considerable uncertainty of prices in agricultural markets, there is a need to substantiate the improvement of approaches to substantiating the optimal combination of market levers with the elements of state regulation. In domestic practice, a wide arsenal of regulatory instruments is used, the lack of systematic and timely introduction of them, proper financial support, transparent economic rules of the game, partnership decency between the state and commodity producers have led to distrust of producers, and the resultant economic returns from these mechanisms were far from the expected results. The paper argues that the priority directions of the state regulation of the agri-food industry of Ukraine support the development of small forms of management - family farms, stimulation of organic production development, agricultural producers compliance with European requirements on quality and safety of food, ensuring the competitiveness of agri-food chains on the basis of the use of grain in the production of livestock products on the domestic market.
\end{abstract}

Keywords: agri-food, state regulation tools, family farms, agri-food chains, added value

JEL Classification: Q 18

\subsection{Introduction}

Agriculture is currently one of the most important sectors of the national economy, which is characterized by its increased sensitivity to the influence of various negative factors of instability and thus it needs some state support. It is obvious that in the conditions of European integration of the domestic economy and international division of labor it is necessary to adopt and implement the economic tools reducing the domestic market protection, ensuring the direct state support focused impact on small agricultural producers and meeting the demands for agro-food industry quality and safety.

As a result, there arises a need to intensify indirect support state regulation including research encouragement, pest control; staff training; providing the activities which promote goods to foreign markets, development; participation 
of the government in programs on commodity producers' income insurance and increase; anticipation of assistance in natural disasters, implementation of regional aid programs, etc.

Thus, the liberalization of agri-food industry requires modernization of the state regulation tools and working out the strategies for the agri-food market development in the long-term outlook. Despite numerous research conducted on this issue it is advisable to justify the need for state support to agriculture, as well as to develop proposals on agri-food market regulation instruments improvement. orientation of agri-food market economic regulation tools on the production ecologization is an important condition for ensuring its effectiveness, as economic entities have a negative impact on the natural environment in the course of their activity, which also needs implementation of European experience into Ukrainian practice under modern conditions.

The aim of the article is to consider the peculiarities of state regulation of the agri-food sector and to develop ITS mechanisms; to substantiate basic areas ensuring balanced dynamic development of the Ukrainian agrarian sector.

\subsection{Data and Methods}

The research methodology is based on foreign and native scientists' articles concerning the necessity to combine market and state regulation of the agro-food products market as well as on the analytical papers and generalization of the experts' opinions in the studied sector of the economy. The methodology includes the analysis of current trends and institutional environment in the field of agriculture and food industry, characteristics of state support of agriculture and agri-food market regulation operational tools. We have used the scientific publications of leading world and national scientists, the results of studies of the State research institutions (concerning the institutional environment in agriculture and rural development) and statistical offices data on agricultural products and food production, processing, sale and consumption. Additional information on the development of private farms that are not registered by the State Statistics Committee of Ukraine are obtained from representatives of regional agricultural management offices, technical assistance projects staff, associations and international donor organizations operating in the territory of Ukraine. Using the aforementioned, empirical studies were carried out towards improving the Ukrainian agri-food market regulation tools.

\subsection{Results and Discussion}

The study of the Ukrainian practice of the regulation and substantiation of its improvement directions in agro-food markets requires, uppermost, 
generalization of the production potential of the investigated sector of the economy as well as the search for ways of its more effective use. Thus, agricultural production sector is one of the leading ones in the Ukrainian economy, the volume of agricultural production of which amounted to UAH 277 billion in 2016, which made $11.6 \%$ of Ukraine's GDP. At the same time, agricultural products accounted for $42.5 \%$ of Ukraine's export in 2016. It is known that Ukrainian agriculture's high potential is ensured by the presence of significant areas of high-quality chernozem. Agricultural land constitutes nearly $71 \%$ of 42.7 million hectares of the Ukrainian territory total area with 32.5 million hectares of the arable land.

The country has formed a combined model of agricultural development, tending to establish large agrarian enterprises. Thus, it is possible to identify the following basic types of economic structures: 1) agricultural holdings and large agrarian firms - complex vertically-integrated structures with a full cycle of production (from the production of agricultural raw material to its processing and sale to the final consumer) (Mesel-Veselyak, 2015). About 20 agrarian holdings companies have more than 100 thousand hectares of land at their disposal. For example, the largest 10 companies carried out their production on an area of 3001 thousand hectares by the end of 2015;2) joint-stock company and cooperatives of various organizational and legal forms, established in the process of collective farm-farm system restructuring through denationalization and privatization of state and collective farms. Most of these enterprises function in the conditions of limited resources, lack of required number of skilled workers, performing mainly "village-preserving" function (Prudivus, 2017); 3) farms and individual holdings - where the farmers produce mainly raw materials (intermediate products), which in the end does not allow to maximize the financial results of their own activities because of the lack of control over the final products full cycle. These economic entities function in a low level of labor mechanization, they grow labor consuming products (potatoes, vegetables, melons, etc.) and sell only surplus products on spontaneous markets and cannot be considered as full-fledged subjects of entrepreneurial activity. At the same time, small private farms produce more than $40 \%$ of gross agricultural products, which makes them a vital element of the country's food security system.

The issue of suspending the moratorium on land sales and the creation of a civilized land market is currently being actively debated in Ukraine, though it can be argued that the country has not created appropriate economic conditions and infrastructure for the land market. Land is being leased, the price of land lease in Ukraine varies from 20 to 170 dollars per hectare a year, depending on the region. After the land reform in Ukraine 27 million hectares were distributed which resulted in 6.9 million land share owners, of which 1.6 million aged over 
70 years old; 1.4 million - died, 0.5 million did not have inheritors. We realize that the land market functioning in Ukraine will increase the country's agricultural investment attractiveness. The data show that Ukrainian commodity producers pay the land lease rate which is several times lower than in other countries. Also there are neither tools for regulating the land market nor specialized infrastructure elements, which allow transparent and civilized development of the market.

Considering the concept of state regulation of the agricultural production market, we share the opinion that it has economic and normative influence on the reproduction processes aiming to adapt it to macroeconomic parameters, mitigate the negative destabilizing effect of seasonal fluctuations in the agrarian market, unanticipated changes in natural, climatic, and other sector specific factors (Mohylny, 2003). There is a similar definition that "state regulation" should be referred to as a system of economic, financial, legal, organizational and social measures implemented by the state in order to ensure the efficient and stable development of agricultural production and the population provision with high quality food at affordable prices (Andriychuk, 2013). Consequently, we have to modernize the conceptual fundamentals of state regulation of the development of the agri-food market, based on, uppermost, economic methods that would meet the requirements of market conditions and ensure the competitive development of agriculture. At the same time, economic tools should be based on the study and scientific analysis of the objective causes of the current state of agricultural enterprises, taking into account the long-term priorities of socio-economic development of rural areas and the definition of the system of measures, forms and methods of state economic regulation of production, which must be provided with appropriate organizational economic mechanism.

State support for agriculture, based on national priorities and taking into account the need for Ukraine's integration into the European Union and the world economic space, is one of the agri-food market regulation tools. The realization of these goals is ensured through the support of entrepreneurs in the following basic areas: legal framework formation; tax, financial and credit policy improvement; information provision; promotion of technologies and innovations; foreign economic activity stimulation; staff training and retraining. The Law of Ukraine "On the Basic Principles of the State Agrarian Policy for the Period till 2015" defines the main components of the state policy in the field of agricultural enterprises support, i.e. it is a complex of legal, organizational and economic measures aimed at improving the efficiency of the agricultural sector of the economy functioning, state policy in the sphere of development of entrepreneurship in agriculture, guaranteeing the state food security, 
transforming the agrarian sector into a highly effective economy competitive on the domestic and foreign markets, preservation of the peasantry as a carrier of Ukrainian nation identity, culture and spirituality, integrated rural development and social problems in rural areas.

Since 2013-2015, the peculiarity of state support to the Ukrainian agri-food sector is that there is a reduction of forms of state support and a sharp decrease in its volumes caused by the limited state resources. In 2016 there was a complete reformatting of state support for business entities, in particular, the mechanism for implementing indirect state support, the special VAT regime was abolished and the system of taxation of agricultural producers changed. Similar changes were made in 2017, which set stipulated the legislative level of the support for the agro-sector, namely, state support for agricultural producers should be at least $1 \%$ of gross agricultural output annually for 5 years, of which not less than $10 \%$ should be spent on purchasing domestic equipment and machines in 2017, $15 \%$ - in 2018, 20\% - in 2019-2021; a new mechanism for state support for agricultural producers has been introduced, state subsidies to be given to agricultural enterprises specializing in growing and breeding the following: vegetables and melons, roots and tubers (including potatoes) will receive state subsidies; mushrooms and truffles; sugar beets; grapes for wine production of and grapes of table varieties; fruits and berries; dairy cattle; cattle and buffaloes for meat production; horses, donkeys, sheep; pigs; poultry, ostriches; obtaining skins of fur farm animals, reptiles and birds; worms, snails, mollusks; bees, honey and wax. An automatic mechanism for state subsidies payment of based on tax reporting data, for which UAH 4 billion to be allocated with the state support to poultry farmers not exceed UAH 2 billion. State support for the development of hops, new gardens, vineyards and berries plots laying was restored; targeted subsidiary per 1 hectare of cultivated land was implemented through approving a new state program of support for farmers cultivating up to 500 hectares; a single register of applications for VAT refunds at export was created (a single register of applications for VAT refunds is used instead of two ones); increased single tax for agricultural producers (Group 4 single tax) (the rate of single tax on Group 4 increases by $17 \%$, which, for example, in the case of arable land, means an increase from $0.81 \%$ to $0.95 \%$ of land normative monetary valuation); the minimum land tax rate increased by $0.3 \%$; the rules for single tax calculation and paying for greenhouse complexes are unified, i.e. land in the closed ground will be taxed rather than the total area of the cultivated land since next year. Also, specialization criterion greenhouse farms (66\% of the proceeds obtained from sale of products grown in a greenhouse soil).

In 2017, the amount of state support is provided in the amount of 5.5 billion UAH. Of these, UAH 4 billion came from the direct support of the agro- 
-industrial complex in the form of grants for: livestock breeding (poultry and eggs, pigs, cattle producers); vegetable growing; gardening; viticulture; berry growing; dairy products processing (cheese, condensed milk, sour cream). In addition, another 1.5 billion is aimed at agrarian sector development programs: (mainly domestic production) and lending programs (agrarian insurance and the launch of the Agricultural Credit Guarantee Fund). Thus, only UAH 3.7 billion can be considered a real budget support for the development of the industry, the rest has no direct influence on the activity of agricultural producers. We believe that it is inappropriate to compare the volumes of state support of agriculture in the dynamics over the years and the leading countries of the world as their amount depends on many factors. However, it is advisable to analyze its effectiveness: each additional hryvnya of state support in the form of VAT provides on average only twenty pennies of growth in productivity in the monetary equivalent in the industry; the efficiency of the single fixed tax is two times lower (Nivievsky, 2017).

According to the data published by the Organization for Economic Cooperation and Development (OECD), Ukraine has the lowest level of support for the commodity producer in the overall support structure of agriculture (41.9\% PSE) among the countries under study, (OECD, 2015). The main direction of supporting the development of the national economy is stimulating business entities through providing non-financial services, in particular, educational support, deregulation of entrepreneurial activity and infrastructure development. The practical experience of OECD member countries reflects the importance of financial support from the commodity producer, which varies from 85 to $92 \%$ of total support funds. The only exceptions are the United States, where the support was only $43.2 \%$, but this is due to the emphasis on consumer protection, though the absolute figures reveal that American commodity producers receive significant financial incentives as compared to other countries. Thus, the return of budget financing of economic entities should be an important step towards the implementation of European strategies for the development of both the general economy and agriculture in particular. Although Ukraine will not be able to fully grant such financial incentives in terms of European integration in reducing the measures of the "yellow box" (measures that have a non-market impact on trade and production).

The following should be attributed to the agri-food market regulation tools in Ukraine: minimum and equivalent prices, customs tariffs, provision of preferential loans, commodity and financial interventions, mortgage purchases, production quotations and export volumes, quality products promotion, additional payments per unit area, special tax regimes, making forward contracts, etc. Given the clarity and timeliness of the introduction of these 
levers, economic mechanisms in the developed countries of the world are successful. We believe that, due to the lack of systematic and timely tools introduction, adequate financial support, transparent economic rules of the game, partnership decency between the state and commodity producers, unfortunately, gave rise to distrust among many agricultural commodity producers, resulting in a low economic return on these mechanisms. There is a need to ensure the full extent of the evolution of the mechanisms of state price regulation through the optimal combination of successive actions and measures of state influence with market levers that will achieve a level of highly productive and competitive agrarian sector.

An example of the effectiveness of the mechanism of state price regulation is the implementation of mortgage purchases of grain from agricultural commodity producers and the introduction of mortgage prices. Such a mechanism involves the insurance of commodity producers from the menacing reduction of market prices for grain in moments of negative impact of market conditions. It should be noted that this was and remains one of the most important problems for agricultural producers. One of the prerequisites for the introduction of mortgage purchases was the crisis economic situation of agricultural enterprises and the inability to replenish working capital at the expense of bank loans (their fees are often much higher than the actual profitability of production and similar fees for loans in developed countries of the world); necessity of commodity producers in the postharvest period of payments for the received monetary and commodity loans used for the harvested yield; the need for the issuance of grain to shareholders in the form of rent for land, equity shares and payroll arrears (Shpychak, 2017) One of the shortcomings in the establishment of mortgage prices in domestic practice was the sharp fluctuations in their level from year to year and the imperfection of the calculations, which caused distrust in of commodity producers, since in determining the size of collateral prices for the next marketing year, the market situation of the past year, rather than the forecast for the following year, was taken into account more.

Since 2005, the state has somewhat changed the approaches to the regulation of the grain market through adopting the Law "On State Support to Agriculture of Ukraine" dated June 24, 2004, No. 1877-IV. This law introduced an intervention procurement mechanism and somewhat changed approaches to mortgage transactions with grain. Consequently, the mechanism of state price regulation involves establishing a corridor of free fluctuations in market prices and the price limits of the state's decision to put into operation market and administrative levers of price regulation. It was established that the free market 
corridor of $2015 / 16$ MP was $39 \%$. In fact, according to similar calculations, the amplitude of seasonal fluctuations was $32 \%$.

In the current situation in Ukraine, it is quite difficult to counteract the critical price fluctuations for agricultural products, as they are influenced by the world market situation only through the mechanisms of state intervention purchases. It was established that the higher efficiency of these mechanisms is manifested through the formation of an intervention fund of non-export oriented types of crop production, which are the objects of state price regulation. In order to ensure food security, forming a public intervention fund and implementing forward purchases of wheat are considered to be appropriate.

Another mechanism for regulating the price offer is the implementation of state forward purchases of grain. The combination of mechanisms for intervention operations, mortgage and forward purchases is a combination of price regulators through which the state policy of ensuring food security is implemented. If long-term market regulation takes place through interventions, as the process for the formation and use of intervention stocks requires a period of more than one year, mortgage and forward purchases serve as short loans. It was established that during 2012-2015 the volume of procurement to the intervention fund was low due to insufficient budget financing. This was also facilitated by the lack of systematic distribution of functions between operators and the insignificant terms for the formation of newly created organizations.

Ukraine has the experience of regulating export-import operations with agricultural crops which is rather valuable both from a methodological and a practical point of view, in particular regarding the introduction of a customs tariff for sunflower seeds export from Ukraine. Adoption of the Law of Ukraine "On the rates of export (export) duties on seeds of certain oilseeds" resulted in significant transformational changes in the oil industry, which was the impetus for its development and as a consequence of the structure of the export of oilseeds. In particular, it was manifested in the radical development of processing capacity due to an increase in investment flows, an increase in the employment. Ukraine ranked first among exporters of sunflower oil on the world market and increased the volume of foreign exchange earnings from foreign trade. In addition, valuable protein feeds remain after the processing, and are further sent to the livestock industry, which eventually ensured an increase in value added in the country.

Consequently, the specific features of the use of the instruments of regulation of the agro-food market in Ukraine are low due to the violation of the integrated and systematic approach, as well as the ignoring of their full realization due to certain subjective and objective reasons, for example, budget 
constraints. That is why there is a need for their improvement on the basis of European practice and specific national requirements.

We believe that, under the current conditions, agricultural regulation instruments should focus on strengthening the export potential of the industry through increased value added in agro-food chains. Thus, the analysis of foreign trade in agricultural products shows that in 2016 the export volumes of sunflower oil are three times lower than the export of corn. However, income from the export of sunflower oil is by 1 billion more than the export of corn.

The calculation of the appropriateness of value added in agro-food chains we conducted on the basis of comparison of the total added value created during the production of grain and its use in the production of milk or meat, taking into account the actual structure of production of livestock products by category of farms. Thus, the calculations convinced that the use of grain in the production of milk and meat exceeds the aggregate value added created for the production of grain and its exports in 1.9 and 2.2 times for milk or meat, respectively. In addition to 236, the calculations show that the processing of grain for livestock products creates additional workplaces, with the production of pork -440 , milk - 930 (Figure 1).

Another area of use of grain in the country, especially in the conditions of our state's energy dependence, is the need to substantiate the economic feasibility of processing their bioethanol. However, the implementation of this strategic direction of the use of grain should be considered through the prism of the priority of full supply of own needs in food.

However, it is possible to realize this advantage of domestic agriculture provided that the quality and safety of products, especially livestock, are ensured. The signing of the Association Agreement with the European Union provoked new challenges and exacerbated quality problems in the agrarian sector of Ukraine. The transition to a European model of food safety has necessitated not only the modernization of the domestic food and feed safety system and the veterinary service, but also the introduction of sanitary and phytosanitary measures in agricultural enterprises in accordance with the requirements of the EU. One of the most problematic solutions to the agrarian sector is the requirement to guarantee the production of safe food based on the introduction of systemic safety methods. We have found that as of 01.01.2017 in accordance with the requirements of international standards in the food industry there were functional SMs: ISO series 9000: 403 units were certified, 46 units were under development and implementation; ISO Series 14000: Certified - 43 units, in stage - 14 units; HACCP: certified - 342 units, in the stage - 150 units; DSTU ISO 22000: certified - 552 units, in the stage - 128 units. 


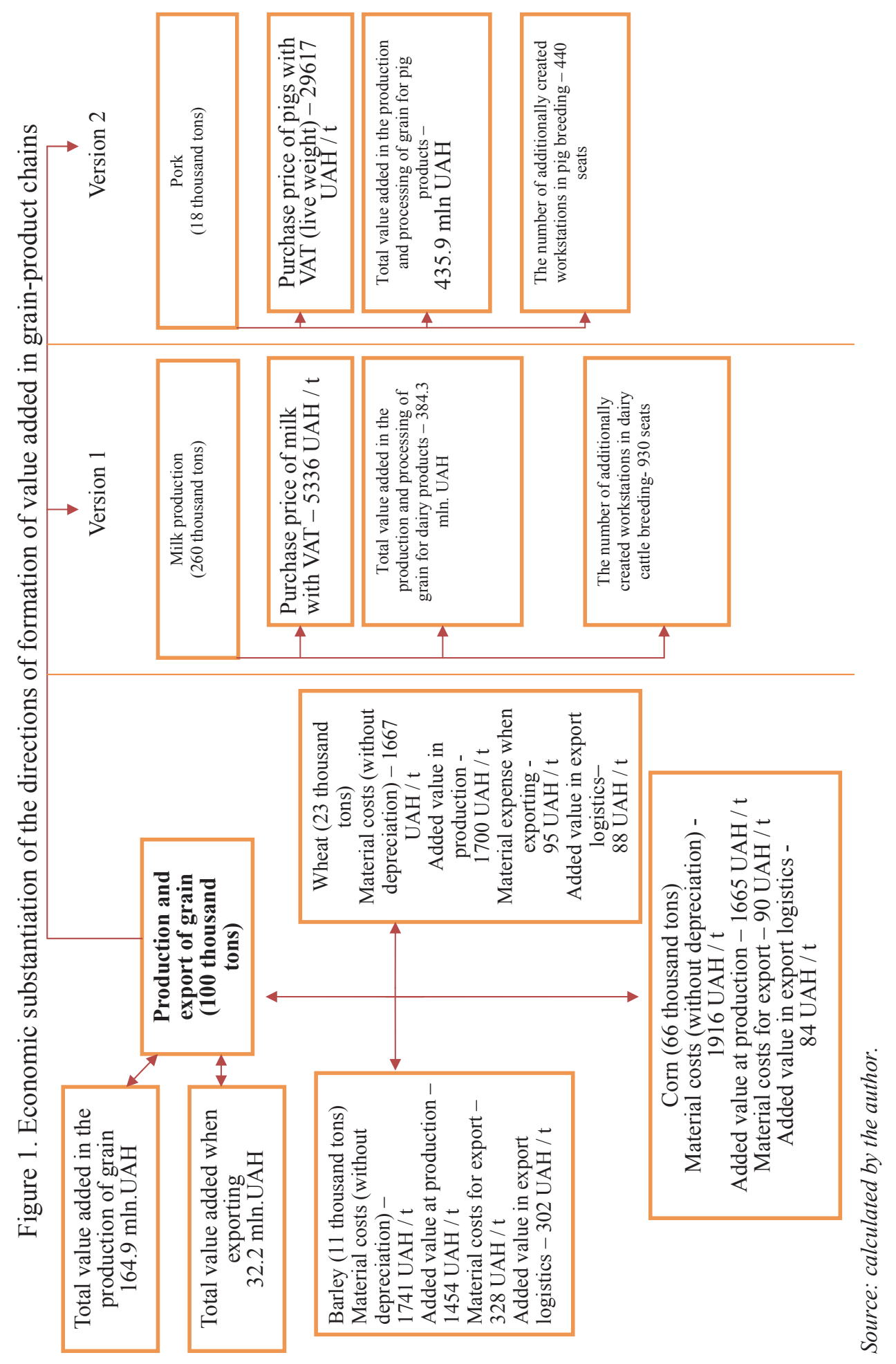


In total, 1340 units are certified in the food industry management systems, and at the stage of development and implementation, there were 338. At the same time, management systems were certified and implemented by almost $90 \%$ of large and medium enterprises (979 enterprises out of 1118 large and medium enterprises $(87.5 \%)$. The total number of processing and food enterprises is 5.5 thousand, including small ones - more than 4.4 thousand. At the same time, the most critical situation in implementation of quality management systems among agricultural producers (44.9 thousand), according to expert estimates, amounts to three percent of enterprises, which were introduced permanently procedures, namely: implemented Safety Systems (HACCP or DSTU ISO 22000: 2007 as part of the AHL); independently audited for production compliance with the minimum requirements of the basic programs (ISO / TS 22002-3: 2011 Program of mandatory preliminary safety measures). Thus, the necessary direction of regulation of the agro-food market should be tools for stimulating commodity producers in the production of high-quality and safe products. We consider it necessary to introduce a two-level system for controlling food safety requirements on the basis of a combination: the first level - the state system for controlling the safety of food and feed and the veterinary service provided by the territorial network of departments, institutions and laboratories of the State Consumer Protection Service; the second level - obligatory confirmation by the Ukrainian exporter of products of animal origin of the equivalence of the current system of safety of the enterprise with the requirements of the model of safety of food and animal feeds operating in the EU, the main element of which is the introduction of the HACCP system and other safety procedures. Depending on the degree of risk, an enterprise is assigned the appropriate risk category - very high, high, medium, low and very low.

An important direction in the future in the state regulation of agriculture is to provide incentives for the development of organic production. In Ukraine in 2016 there were only 390 organic production enterprises with an area of 421 thousand hectares. Ukraine ranks 22nd in the world in areas allocated for organic production. Export volumes of organic products from Ukraine exceed domestic consumption and in recent years ranged from 35 to 50 million euro (Martynyuk M.P., 2017). Although this segment of production in Ukraine tends to increase, the main constraints are: the lack of development of the domestic market, the dominance of imported organic products in the market, the lack of development of the infrastructure of trade in organic products, the imperfection of the regulatory framework, limited access on the external markets of organic products, lack of state support, lack of educational work. The financial support, preferential taxation, increase of supplements to the purchase price, preferential 
prices for services and means of production, state insurance, promotion of organic products among producers and consumers, and the creation of a rationalized market for organic products can be instruments for implementing state incentives for organic production.

For agrarian policy in Ukraine, the lack of a strategic vision of the final model of the rural system, in particular the existence of a disparity in the legal regulation of economic freedom between the corporate and private sectors, is characteristic, as the small, especially self-employed forms of farming in the countryside are virtually ignored. Thus, the Concept of the State Target Program for the Development of the Agrarian Sector of the Economy for the period up to 2021, aimed at "creating organizational and economic conditions for the effective socially oriented development of the agrarian sector, ensuring stable production of quality and safe domestic agricultural products and industry by agricultural raw materials, production with high added value, increase in volumes on the world market of agricultural products and foodstuffs". Within the framework of this program, ways and means of solving problems of agricultural development related to support of existing and creation of new economic entities - commodity producers of agricultural products, in particular family farms (Concept, 2015).

Modern trends in European integration processes challenge the domestic producers of agricultural products, many of which are not in line with the new requirements of the international agro-food market, especially in terms of quality and product safety. Among the main obstacles are: limited financial and credit resources for modern technical support of production processes, increased activity of agro-holding corporatization specializing in the production of exportoriented products (mainly in the form of raw materials), ignoring agroecological and technical conditions of production, inconsistency with the European rural development strategy territories. Under such conditions, the state should improve and strengthen the agrarian policy to promote the development of small-scale agricultural production; special attention should be paid to stimulating the realization of the entrepreneurial potential of landowners by acquiring them the status of a producer of agricultural products in the form of a family farm.

As you know, in the countries of the European Union, family farms are a fundamental element of regional development of rural areas. In this aspect, these economic entities should be considered not only as structures of a purely industrial direction but also as a centre for the preservation of the cultural heritage and for ensuring the integrity of the rural communities' society. Within the framework of CAP (European Common Agricultural Policy), European 
countries give only a secondary role to the production function of family farms, the primary task of these structures is to determine the development of rural areas and support for national cultural features (Zimbahl, 2012). At the same time, preservation of family-owned farms status of the state support entity is achieved due to their significant contribution to the sustainable development of the national economy and the rational use of land resources.

Thus, in 2015, there were 4.1 million private peasant farms operating in Ukraine, a significant proportion of which can be attributed to the category of small-scale production, since they set the balances of agricultural produce, although they do not have legal personality. In the dynamics of the last ten years, the number of OSG annually decreases by 82.9 thousand units, according to our calculations their number will decrease to 3,012 thousand units by 2030 . As a trend line, we selected an exponential function with a high determination coefficient $\mathrm{R}^{2}=0.9718$, which realistically predicts the future situation in accordance with the general tendencies of a rapid decrease in the number of rural population. At the same time, the generalization of normative legal provision of agricultural production in rural areas, at present, there is no single clear approach to the policy of development of forms of small-scale farming in the countryside (Stelmashchuk, 2010). In this aspect, the role of executive bodies of Ukraine in determining strategic goals of agricultural production development, optimization of its production and social infrastructure, ensuring proper servicing, development of service and credit cooperation, marketing and other measures to improve the functioning of market infrastructure objects from the purpose of maximizing the interests of producers of agricultural products. According to the results of the expert assessment of representatives of business associations, it was established that the most acute problem of the development of small and medium enterprises in Ukraine is corruption in various forms and manifestations in interaction with the authorities (Hodko, 2015). The expediency of developing a mechanism of state support for the development of small forms of management, which should meet the following conditions: harmonization of state structural policy with program documents for the development of rural areas and agriculture and small businesses; assessment of the institutional environment of the functioning of family farms and the problems of their creation; definition of forms, methods, tools and sources of state support; infrastructure and regulatory support for supporting family businesses. At the same time, the mechanism of state support for the development of family-owned farms in Ukraine should include stimulating tools and measures for support in relation to: improvement of technical and technological support for agricultural production, its adaptation to the requirements of international standards; 
expanding the channels of product sales through overcoming barriers to entry, ensuring fair competition; ensuring the proper level of economic and financial-credit support; improvement of the regulatory environment for the conduct of entrepreneurial activity by family farms, etc.

\subsection{Summary and conclusions}

The research proves that there has existed rather powerful arsenal of state price regulation tools in the national legislation in different periods, but the reason for their low efficiency is the lack of systemic and timely introduction, proper financial support, partnership responsibility in fulfilling the obligations and agricultural manufacturers trust. The transformation of the instruments of state regulation of the agri-food market should be oriented towards supporting the formation of added value in agri-food chains, the development of organic production, the achievement of compliance of quality indicators and product safety with European requirements, and encouraging the development of family farms and rural areas. It is estimated economically that one of the ways to reduce the dependence of export-oriented crop production on the world price volatility is diversification of the use of products in line with alternative options for value added increase within the country, in particular, in grain production for livestock .

It is established that the current state of state support to agricultural producers is characterized by the absence of a clear mechanism for their stimulation and ensuring the effectiveness of economic activity. The state is now unable to organize an effective system of indirect support, including the creation of an effective mechanism for transforming peasant farms into family farms. Effective tools for stimulating the development of the European model of family farms in Ukraine may be the following: tax rebates on the achievement of a certain level of income, payment of early retirement pensions to family farmers, assistance in the manufactured products processing, active involvement of young people into production the through the provision of certain financial preferences, price support, support for the production of environmental products, etc.

\section{References}

1. Mohylny O. M. The main contradiction in the agrarian sector of the economy reform / O. Mohylny // Economy of Ukraine. - 2003. - №4. - P. 43-48.

2. Andriychuk V.G. Economy of enterprises of the agro-industrial complex. $\mathrm{K} .: \mathrm{KNEU}, 2013 .-780 \mathrm{p}$. 
3. Law of Ukraine "On the Basic Principles of the State Agrarian Policy for the Period until 2015" dated October 18, 2005 No. 2982-IV. [Electronic resource]. - Mode of access: http://zakon2.rada.gov.ua/laws/main/2982-15

4. Oleh Nivievsky: Direct subsidies to agribusinesses - a way to nowhere / Electronic resource: Access mode: http://agravery.com/en/posts/show/olegnivevskij-prami-dotacii-agropidpriemstvam-ce-slah-v- nikudi

5. Estimate of support for agriculture: Reference tables [el. Res.] // Organization for Economic Co-operation and Development. - 2015 - Mode of access: $\mathrm{http}: / /$ stats.oecd.org/viewhtml.aspx?QueryId $=66824 \& \mathrm{vh}=0000 \& v f=0 \& 1 \& \mathrm{l}=\&$ lang $=$ en

6. Theoretical-methodological and practical bases of pricing: monograph / O. M. Shpychak, O. V. Bodnar, O. O. Shpychak. Ed O. M. Shpychak. Kyiv: TsP "Komprint", 2017. - 545 p.

7. Varchenko O.M. Formation of the European model of food safety and its implementation at the enterprises of the agrarian sector of Ukraine / O.M. Varchenko, D.F. Krysanov, I.V. Artimonova // Economy and management of agrarian and industrial complex, 2017. - №.1-2. - 15-29.

8. Martyniuk M.P. State regulation of organic production: state and prospects of development // Organic production and food safety. - Zhytomyr: ZNAMEU, 2017. - 436 pp., P.5-10.

9. Zimbahl R. Agriculture's Ethical Horisont / R. Zimbahil. - London: Elsevier Inc., $2012-239 \mathrm{p}$.

10. Stelmashchuk A.M. Small business - the basis of sustainable development of rural territories / A.M. Stelmashchuk // Sustainable development of the economy. - 2010. - No. 2. - P. 54-58.

11.Development of Small and Medium Enterprise in Ukraine: Problems, Needs, Perspectives / [Hodko N., Baldych N., Yaechenya O., Chorny L.]. - K .: Center for Public Expertise, Center for International Private Enterprise, 2015. $-44 \mathrm{p}$.

12.Mesel-Veselyak V.Ya. Theoretical-methodological and normative-legal support for the transformation of the agrarian sector of Ukraine's economy to market conditions of management, scientific support and implementation efficiency / V.Ya. Mesel-Veselyak, M.M. Fedorov // Economy of the agroindustrial complex. $-2015-$ N 7. - P. 5-24.

13.Prudivus L.V. State support of entrepreneurship in agricultural production of Ukraine on the basis of income sustainability / L.V.Prodivus // Bulletin of Agrarian Science. - 2017. - No. 4. - P. 65-69.

14.Gubeny Yu.E., Koverko Yu.A. Development of private peasant farms under conditions of administrative decentralization. // Economy of the agroindustrial complex, 2017. - No. 1.- P.68-73.

15.Holubev A. FARMS IN UKRAINE: TRENDS OF DEVELOPMENT, ECONOMIC AND SOCIAL NATURE / Bulletin of APPSM, 2017, No. 1. P. 58-63. 